\title{
Review Article \\ Potential of Zeolite and Algae in Biomass Immobilization
}

\author{
Seyed Amirebrahim Emami Moghaddam, ${ }^{1}$ Razif Harun (D), \\ Mohd Noriznan Mokhtar, ${ }^{2}$ and Rabitah Zakaria ${ }^{2}$ \\ ${ }^{1}$ Department of Chemical and Environmental Engineering, Universiti Putra Malaysia, Serdang, 43400 Selangor, Malaysia \\ ${ }^{2}$ Department of Process and Food Engineering, Universiti Putra Malaysia, Serdang, 43400 Selangor, Malaysia \\ Correspondence should be addressed to Razif Harun; mh_razif@upm.edu.my
}

Received 22 September 2018; Accepted 25 November 2018; Published 12 December 2018

Academic Editor: Kok Tat Tan

Copyright (C) 2018 Seyed Amirebrahim Emami Moghaddam et al. This is an open access article distributed under the Creative Commons Attribution License, which permits unrestricted use, distribution, and reproduction in any medium, provided the original work is properly cited.

\begin{abstract}
The interest in utilizing algae for wastewater treatment has been increased due to many advantages. Algae-wastewater treatment system offers a cost-efficient and environmentally friendly alternative to conventional treatment processes such as electrocoagulation and flocculation. In this biosystem, algae can assimilate nutrients in the wastewater for their growth and simultaneously capture the carbon dioxide from the atmosphere during photosynthesis resulting in a decrease in the greenhouse gaseousness. Furthermore, the algal biomass obtained from the treatment process could be further converted to produce high value-added products. However, the recovery of free suspended algae from the treated effluent is one of the most important challenges during the treatment process as the current methods such as centrifugation and filtration are faced with the high cost. Immobilization of algae is a suitable approach to overcome the harvesting issue. However, there are some drawbacks with the common immobilization carriers such as alginate and polyacrylamide related to low stability and toxicity, respectively. Hence, it is necessary to apply a new carrier without the mentioned problems. One of the carriers that can be a suitable candidate for the immobilization is zeolite. To date, various types of zeolite have been used for the immobilization of cells of bacteria and yeast. If there is any possibility to apply them for the immobilization of algae, it needs to be considered in further studies. This article reviews cell immobilization technique, biomass immobilization onto zeolites, and algal immobilization with their applications. Furthermore, the potential application of zeolite as an ideal carrier for algal immobilization has been discussed.
\end{abstract}

\section{Introduction}

Water is the basic element of life on earth. The demand for water in the entire world is growing fast for the domestic, agricultural, and industrial activities. However, the availability and quality of water resources face severe threats due to the industrialization and rapid economic development producing a huge amount of wastewater. This wastewater contains organics, suspended solids, and hazardous materials such as heavy metals which are not biodegradable. These materials tend to accumulate in organisms and potentially cause severe contamination and diseases due to poor water management $[1,2]$. Hence, wastewater treatment is essential to prevent deterioration of the environment and solve the issue of water shortage and health.
Wastewater treatment consists of removing or decreasing a number of hazardous substances such as chemicals and biological pollutants [3]. The selection of the treatment approaches is strongly influenced by their characteristics and compositions. Various wastewater treatment approaches have been used such as chemical, physical, and biological approaches [3]. Advanced oxidation, electrocoagulation, and flocculation are the most common methods of physical and chemical treatment whereas suspended or activated sludge process is an example of the biological treatment that is widely applied [4]. Although these conventional methods have successfully treated various wastewater sources, they have some limitations. The physical and chemical methods face the problems of high-energy requirements, incomplete removal of heavy metals, generation of secondary pollutants, 
TABlE 1: Advantages of cell immobilization over suspended cell.

\begin{tabular}{lr}
\hline Advantages of immobilization & References \\
\hline Simplifying biomass harvesting & {$[3,4,13]$} \\
Higher cell density & {$[3,4]$} \\
Enhancing operational stability & {$[3,4]$} \\
Avoiding cell washouts & {$[3]$} \\
Increasing cell resistance to unfavorable factors & {$[13]$} \\
(temperature, acidity, and toxic compounds) & {$[3]$} \\
Occupying less space & {$[3]$} \\
Easier to handle & {$[3,14]$} \\
Using repeatedly
\end{tabular}

complex operation, and high cost [4-6], and the biological method deals with the problems of the easy washout and low biomass concentration [4].

The use of microalgae to treat wastewater is currently of global interest due to its advantages. On the one hand, microalgal cells have the ability to uptake nutrients such as phosphorus, nitrogen, and ammonium as well as heavy metals to reduce BOD in wastewater [7-10] and also simultaneously capture the carbon dioxide from the atmosphere during photosynthesis decreasing the greenhouse gaseousness $[11,12]$; on the other hand, the wastewater can be considered as a cheaper nutrient source for the growth of microalgae. However, at the current state, the biological nutrient removal technologies, including the use of microalgae, have not been competitive in the wastewater industries. The main issue contributes to the high cost of recovery of the treated effluent and biomass using current dewatering methods such as centrifugation and filtration [11]. To overcome the issue, the existing cell suspended method can be replaced with the immobilization method. The advantages of immobilization over the suspended method have directed researchers to discover in detail the system $[3,4,13,14]$. Not only can cell immobilization simplify the separation process, but it also offers other advantages such as higher cell density, higher productivity, better cell stability, and biomass recirculation $[3,4,13,15,16]$. One of the most important parts in the immobilization technique is selecting a suitable carrier. As the common carriers such as alginate and polyacrylamide face some drawbacks like low stability and toxicity, respectively $[13,17]$, finding and using a new carrier with ideal characteristics (i.e., nontoxic, stable, and cheap) can solve existing problems. One of the ideal candidates applied for the immobilization is zeolite. Zeolites are inorganic materials that are resistant to microbial degradation and also costeffective $[4,18]$. The application of zeolites is in agriculture, catalysis, building industries, energy, and treatment of water streams $[1,19-45]$. In addition to these common applications, they have been used as a carrier for biomass immobilization $[5,15,46-55]$ and applied in different areas such as production of high-value products $[15,46,47,49,50,53]$ and metal/nonmetal removal $[5,48,51,52,54,55]$. Various kinds of microorganisms have been used for the immobilization onto zeolites such as bacteria $[5,15,49-54]$ and yeast $[46,47]$.
This article reviews the immobilization technique, biomass immobilization onto zeolites as special carriers, and algal immobilization. Furthermore, the potential application of zeolite as an ideal carrier for algal immobilization has been discussed.

\section{Immobilization}

Immobilization is defined as a process of cell attachment and/or cell inclusion to or into a carrier volume as a support $[13,56]$. Cell immobilization has a number of advantages over suspended cells shown in Table 1. Immobilized systems have been applied in various applications such as the production of noncontaminant energy $[57,58]$, wastewater bioremediation [13], toxicity measurement $[58,59]$, metabolite production $[58,59]$, and stock culture management [3].

2.1. Types of Immobilization. The process of microorganism immobilization can be done by various mechanisms, including adsorption, covalent bonding, cross-linking, encapsulation, and entrapment in a matrix [3, 4, 13, 18, 50, 59-65]. Table 2 shows various types of immobilization method along with their advantages and disadvantages. According to Eroglu et al. 2015 and Godlewska-Żyłkiewicz et al. 2003, the most common immobilization methods are cell attachment and cell entrapment $[3,64]$. In immobilization via adsorption, the attachment is done without using intermediate molecules while, in the covalent attachment, the "bridge-molecule" is used for functionalization of the support [63]. In the entrapment method, cells are captured into a three-dimensional gel lattice. This kind of supports can be either natural or synthetic $[3,59,60,65]$. The method is often used for capturing microorganism in suspended solution. Due to the porous structure of polymers, different kinds of metabolites can be easily diffused through the matrices $[4,18]$.

2.2. Operational Modes of Immobilization. The immobilization process can be done in two operational modes: passive and active $[13,57]$. The passive mode is based on the natural ability of the microorganism to attach to the natural or synthetic carriers (solid or gel-like surfaces) and grow on them $[4,13,57,59]$. The mechanisms for the carrier attachment involve physical (electrostatic and hydrophobic interactions) 


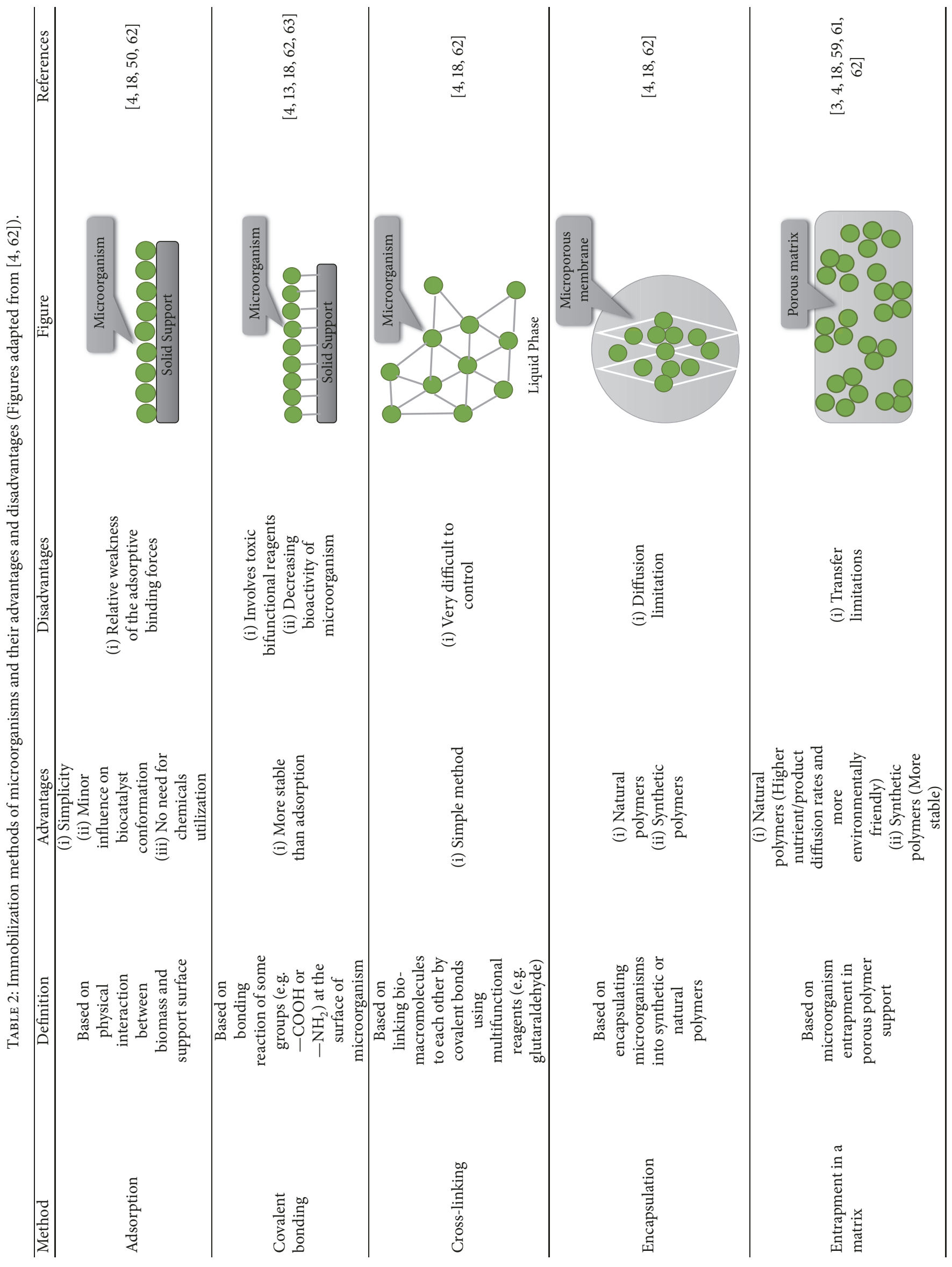



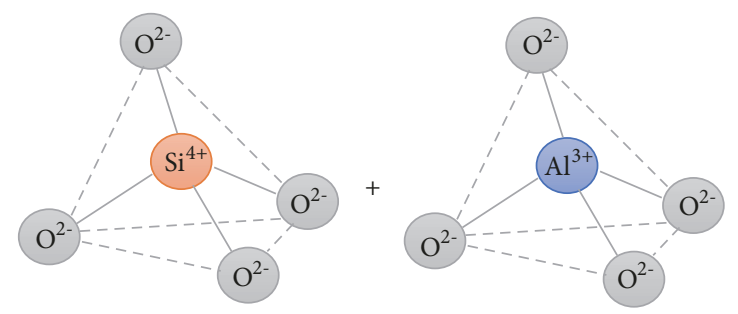

Primary Building Unit (PBU)

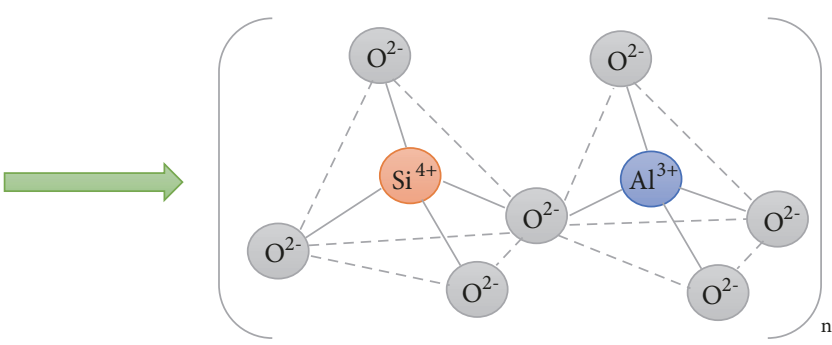

Secondary Building Unit (SBU)

FIGURE 1: Primary and secondary building units of natural zeolite (adapted from [69]).

and chemical (covalent bond formation) $[4,13]$. The most common electrostatic interactions involved in the initial stage of adsorption are ionic and hydrogen bonding [4]. In contrast, in the active mode, there is not any dependence on the natural ability of cells for the attachments [13] and the mechanisms for the carrier attachment are covalent bonding, cross-linking, and inclusion of cells into the carrier $[4,13,57]$. In addition, the carrier type is either synthetic or natural $[13,57]$.

2.3. Ideal Carrier for Immobilization. One of the important parts in the immobilization process is selecting a suitable carrier. According to Vasilieva et al. 2016 and Das and Adholeya 2015, there are two types of carriers that can be used for cell immobilization: natural and synthetic [4, 13]. The ideal carrier for cell immobilization has to fulfill some characteristics such as porous structure, light weight, being inert, nonbiodegradable in the test condition, and nontoxic, no inhibition, and allowing mass transfer. Also, the carrier should have high stability, including chemical, mechanical, and biological, be environmentally friendly and cheap, and provide an irregular, rough surface for colonization $[4,13$, $66,67]$. To date, various supports have been used in cell immobilization, including organic and inorganic supports. Organic supports have higher absorptivity and larger forms of reaction groups like amino, hydroxyl, and carboxyl than inorganic supports [4]. Alginate, agar, carrageenan, polyacrylamide (PAM), and polyvinyl alcohol (PVA) are some of the examples of organic carriers. Another form of carrier materials is inorganic such as clay, activated charcoal, and zeolite. These materials have some characteristics, including resistance to microbial degradation, suitable thermostability performance, and cost-effectiveness $[4,18]$.

\section{Biomass Immobilization onto Zeolites}

3.1. Zeolite. Zeolites are inorganic materials whose structures contain Primary and Secondary Building Units, PBU and SBU, respectively. $\mathrm{PBU}$ builds up from $\mathrm{SiO}_{4}$ and $\mathrm{AlO}_{4}$ tetrahedra and they are connected via oxygen ions to form SBU. The SBU are then linked into a three-dimensional crystalline structure and form a honeycomb shape $[41,68,69]$. Due to the substitution of $\mathrm{Si}^{4+}$ by $\mathrm{Al}^{3+}$, the charge of the framework is negative, which is balanced by monovalent or divalent cations located together with water $[38,69]$. As a result, because of surface negative charge, zeolites are capable of exchanging ions with an external medium $[38,69]$; hence, they can be used for metal ion removal in water environments. Figure 1 shows primary and secondary building units of natural zeolite.

There are three types of zeolite characterized as natural, modified, and synthetic. Up to now, over forty types of natural and one hundred types of synthetic or modified zeolite have been reported [30]. Natural zeolites are of common forms such as clinoptilolite, mordenite, etc., but the most abundant one is clinoptilolite $[30,38]$. The natural zeolites are known in the world for their characteristics, including ion exchange capacities, high porosity, large specific surface area, and low cost $[19,26,45,51]$. However, the problem with the natural zeolites is that their ion-exchange capacity is relatively low [19]. Hence, some modifications are needed to solve this issue, where modified and synthetic zeolites are the candidates. Modified zeolites, for the most part, are obtained via either acid or base treatment and surfactant modification methods. Meanwhile, synthetic zeolites are obtained from some materials like clay minerals, kaolin, waste materials, etc. [30]. From the point of view of cation exchange capacity and sorption performance, both modified and synthetic zeolites have higher capacity and performance than the natural zeolite [30]. However, nonnatural zeolites have environmental issues such as increasing sodium level, removing calcium, and increasing the $\mathrm{pH}$ of the medium to 8.5 [22]. Hence, although natural zeolites have low efficiency in metal ion removal, they are natural with low risk in terms of environmental perspectives.

Zeolites have various applications in catalysis, agriculture, building industries, energy, and removal process of oil, ammonium, metal ions, etc. from water streams [1, 19-45]. The ratio of $\mathrm{Si} / \mathrm{Al}_{2}$ in zeolite structure is used to indicate the hydrophobicity of zeolite. A higher ratio of $\mathrm{Si} / \mathrm{Al}_{2}$ indicates a higher degree of hydrophobicity and lower ion-exchange capacity [70]. In addition to common applications of zeolites, another significant application of the material is for biomass immobilization as suitable carriers.

3.2. Zeolite-Immobilized Biomass and Its Applications. Many advantages can be offered by zeolite-immobilized biomass. According to Weiß et al. 2010 and Milán et al. 2003, zeolites 
TABLE 3: Various types of zeolite-immobilized biomass and their applications.

\begin{tabular}{|c|c|c|c|c|}
\hline Type of zeolite & Immobilized biomass & Applications & Findings & References \\
\hline Clinoptilolite & $\begin{array}{l}\text { Acidogenic biomass } \\
\text { (anaerobic sludge) }\end{array}$ & $\begin{array}{l}\text { Copper and iron } \\
\text { removal }\end{array}$ & $\begin{array}{l}\text { Biosorption capacity } \\
\text { of } 28.65 \mathrm{mg} / \mathrm{g} \text { copper } \\
\text { and } 34.72 \mathrm{mg} / \mathrm{g} \text { iron }\end{array}$ & [48] \\
\hline $\begin{array}{l}\text { Mg-modified } \\
\text { zeolite }\end{array}$ & $\begin{array}{l}\text { Lactobacillus } \\
\text { rhamnosus }\end{array}$ & $\begin{array}{l}\mathrm{L}(+) \text { lactic acid } \\
\text { production }\end{array}$ & $\begin{array}{l}\text { Overall productivity } \\
\text { of } 1.41 \mathrm{~g} / \mathrm{L} / \mathrm{h}\end{array}$ & {$[15]$} \\
\hline Zeolite & $\begin{array}{l}\text { Actinobacillus } \\
\text { succinogenes }\end{array}$ & $\begin{array}{l}\text { Succinic acid } \\
\text { production }\end{array}$ & $\begin{array}{c}\text { Productivity of } 2.83 \\
\text { g/L h }\end{array}$ & [49] \\
\hline $\begin{array}{l}\text { Zeolite (type } \\
13 \mathrm{X})\end{array}$ & $\begin{array}{l}\text { Lactobacillus } \\
\text { rhamnosus }\end{array}$ & $\begin{array}{l}\text { Lactic acid } \\
\text { production }\end{array}$ & $\begin{array}{l}\text { Productivity of } 1.69 \mathrm{~g} / \\
\text { L }\end{array}$ & {$[50]$} \\
\hline $\begin{array}{l}\text { Chilean natural } \\
\text { zeolite }\end{array}$ & $\begin{array}{c}\text { Bacterial } \\
\text { microorganism }\end{array}$ & $\begin{array}{l}\text { Ammonium } \\
\text { removal }\end{array}$ & $\begin{array}{l}\text { Adsorption capacity } \\
\text { of } 2.7 \mathrm{mg} / \mathrm{g}\end{array}$ & [51] \\
\hline Zeolite 13X & Arthrobacter viscosus & $\begin{array}{l}\text { Chromium } \\
\text { removal }\end{array}$ & $100 \%$ removal & {$[52]$} \\
\hline $\begin{array}{l}\text { Trace metal } \\
\text { activated zeolite }\end{array}$ & $\begin{array}{l}\text { Hemicellulolytic } \\
\text { bacteria }\end{array}$ & Biogas production & $\begin{array}{l}\text { Methane increase by } \\
53 \%\end{array}$ & [53] \\
\hline Zeolite $\mathrm{NaY}$ & Escherichia coli & $\begin{array}{l}\text { Chromium, } \\
\text { cadmium, iron, } \\
\text { nickel removal }\end{array}$ & $100 \%$ removal for iron & [5] \\
\hline Natural zeolite & Arthrobacter viscosus & $\begin{array}{l}\text { Chromium } \\
\text { removal }\end{array}$ & $18 \%$ removal & {$[54]$} \\
\hline Natural zeolite & $\begin{array}{c}\text { Anaerobic } \\
\text { microorganisms }\end{array}$ & $\begin{array}{l}\text { Anaerobic } \\
\text { treatment of } \\
\text { Wastewater }\end{array}$ & $\begin{array}{c}\text { COD removal } \\
\text { efficiencies as high as } \\
90 \%\end{array}$ & [55] \\
\hline Natural zeolite & $\begin{array}{l}\text { Saccharomyces } \\
\text { cerevisiae }\end{array}$ & $\begin{array}{c}\text { Ethanol } \\
\text { fermentation }\end{array}$ & $\begin{array}{l}\text { Ethanol concentration } \\
2 \%(\mathrm{w} / \mathrm{v})\end{array}$ & {$[46]$} \\
\hline Zeolite & $\begin{array}{l}\text { Saccharomyces } \\
\text { cerevisiae }\end{array}$ & $\begin{array}{c}\text { Alcoholic } \\
\text { fermentation }\end{array}$ & $\begin{array}{c}\text { Productivity of } 35.6 \mathrm{~g} \\
\text { ethanol/L.h }\end{array}$ & {$[47]$} \\
\hline
\end{tabular}

were used as a support for microorganism immobilization in anaerobic reactors resulting in stabilizing and optimizing process efficiency $[53,71]$. Also, the immobilized biomass obtained after the process can be used for other applications as it has a high worth. It can be considered as biomass enriched feed [15] and useful for animals [50]. In addition, Djukić-Vuković et al. 2013 reported that a simple cell separation in the fermentation area and cell reuse in repeated batch cycles were achieved by immobilization [50]. Also, FigueroaTorres et al. 2016 reported that the acidogenic biomass immobilized in clinoptilolite is a low-cost biosorbent for copper and iron removal [48]. This is an important finding that further can make the whole process more feasible for industrial applications. There are several factors interfered in the attachment process between biomass and zeolite. As reported by MacArio et al. 2007, zeolites showed a significant property towards the immobilization process, including hydrophobic or hydrophilic behavior, acid or base character, chemical and mechanical resistance, great morphology, a total surface area, and easy water dispersion/recuperation. Also, the researchers reported that zeolites included a great number of $\mathrm{Si}-\mathrm{OH}$ groups that play key roles in the adsorption process [63]. According to Djukić-Vuković et al. 2013 and Kubota et al. 2008, the surface of zeolite can adsorb biopolymers such as proteins, nucleic acids, RNA, and DNA in a selective manner as well $[50,70]$. Due to these reasons, zeolites can adsorb microorganisms on their surfaces, and they can be used as an efficient [50] and potential [72] carrier in the process of biomass immobilization. On the other hand, the surface of microorganisms is full of various components, such as polysaccharides [70]. Exopolysaccharides (EPS) can have a protective role in unfavorable conditions and act as adhesives for interactions with various substrates and also as a promoter for cell aggregation and biofilm formation $[50,73]$. There is a possibility that EPS may contribute to the process. According to Pazos et al. 2010 and Lameiras et al. 2008, under stress conditions in a diluted medium, the biofilm formation can increase the production of EPS, resulting in the formation of coherent biofilm with a powerful adhesion to the carrier surface [52, 54]. Djukić-Vuković et al. 2013 used Lactobacillus rhamnosus for immobilization onto zeolite and they reported that the bacterium produced EPS and formed a sticky layer on the surface of the microorganism; hence, it aided the immobilization process [50]. Table 3 shows various types of zeolite-immobilized biomass and their applications.

3.2.1. Production of High-Value Products. The zeolite-immobilized biomass can be used for the production of some metabolites such as acids [15, 49, 50] and alcohols [46, 47]. In a research done by Shindo et al. 2001, natural zeolite abilities were compared with glass beads for the immobilization and alcohol fermentation. The results showed that the immobilization capacity and alcohol fermentation activity of natural zeolite were 2- and 1.2-fold higher than 
those of glass beads, respectively [46]. Also, the modified (or activated) zeolite as a biomass support can increase process yields. Weiß et al. 2010 used hemicellulolytic bacteria for the immobilization on trace metal activated zeolite and their results showed an increase of methane by 53\% compared to without immobilization. The study also found that the modification of zeolite by trace metal elements such as iron, magnesium, cobalt, and nickel favors microorganisms to be grouped in small microcolonies and supply cofactors in the enzyme biosynthesis process [53]. One of the main purposes of the immobilization technique, as mentioned before, is recycling the immobilized materials. The more the number of repetitions is, the higher efficiency and low cost will be. Djukić-Vuković et al. 2016 used Mg-modified zeolite as a support for Lactobacillus rhamnosus immobilization and their results showed that the attachment of biomass on zeolite was strong and stable resulting in a continuous colonization during four cycles [15]. In addition, Shindo et al. 2001 used natural zeolite as a support for Saccharomyces cerevisiae in a bioreactor and reported that no breakage of the carrier during continuous alcohol fermentation for over 21 days was achieved [46]. Also, MacArio et al. 2007 found that the enzyme immobilized on zeolitic supports could catalyze some cycles, but it continuously leached from the support [63].

3.2.2. Metal Removal. The main pollutant removal mechanisms by microorganisms include assimilation, biodegradation, and biosorption [4]. Assimilation is the process of nutrient ingestion (e.g., carbon, nitrogen, and phosphorus) from wastewater by microorganisms and using them for their growth. Biodegradation is explained as the decomposition/chemical disbanding of organic materials through microorganisms/microbial aggregates aerobically and/or anaerobically. Biosorption is a phenomenon in which microorganisms can adsorb heavy metals and organic and inorganic materials via various processes, including complexation, flocculation, ion exchange, etc. $[4,74]$. There are various significant factors that interfere in the biosorption process. Figueroa-Torres et al. 2016 mentioned that there are two factors that are significantly contributing during the biomass selection as potential biosorbent, including its availability and price [48]. During the removal of pollutants, all the processes of assimilation, biodegradation, and biosorption simultaneously happen $[4,74]$. In the process of metal uptake by biomass, various factors are responsible for the nature of the process and determination of the binding mechanism, including chemical groups (e.g., structural polysaccharides, amino and phosphate groups in nucleic acids, carboxyl groups in proteins. etc.) and also solubility and polarity [3, 4, 54, 74-76]. Quintelas et al. 2009 reported that the functional groups existing on the biomass (Escherichia coli), including carboxyl, hydroxyl, and phosphate groups, were probably the main binding sites in the biosorption process. It was also observed that the metal affinity to the biofilm pursued the arrangement of $\mathrm{Fe}(\mathrm{III})>\mathrm{Ni}(\mathrm{II})>\mathrm{Cd}(\mathrm{II})>\mathrm{Cr}(\mathrm{VI})$. This preference may be described on the basis of metal ion electronegativity and cation/anion state [5]. In addition, various physicochemical forces such as covalent bonding, van der Waals bonding, ion exchange, and dipole/dipole interactions are other factors that can interfere in ion uptake on the adsorbent $[3,76]$.

As suspended biofilm alone cannot be applied especially in the continuous treatment process and also zeolite, in turn, cannot retain all the metals, there is a need to evaluate the synergetic effect between biosorption ability of biomass and retention capacity of zeolite [5]. To date, several types of microorganisms have been used for the immobilization onto zeolites in the biosorption area $[5,48,51,52,54,55,66,77-$ 80]. The process efficiency of biosorption is dependent on operational parameters such as biomass concentration and pH [52]. Pazos et al. 2010 used a bioreactor, including a biofilm supported on zeolite $13 \mathrm{X}$ and their results revealed that the biomass concentration and $\mathrm{pH}$ were the key variables for the metal ion removal. Also, the process efficiency was improved by adjusting biomass concentration and $\mathrm{pH}$ values. They successfully reached up to $100 \%$ removal of the metal ion under the optimized conditions [52]. Using other supports along with zeolite can also be effective in increasing the process yield. Lameiras et al. 2008 used minicolumns including Granular Activated Carbon (GAC) and a natural zeolite as a support for biomass immobilization and found that the combination of GAC and zeolite columns covered with biofilm gave better performance of $42 \%$ removal than individual GAC (19\%) and zeolite (18\%) [54]. Another interesting issue with the system is whether the zeolite by itself is effective in the process efficiency or just acts as a support for biomass. Monge-Amaya et al. 2013 used aerobic biomass biofilm for the immobilization on untreated clinoptilolite zeolite and Energy-Dispersive Xray Spectroscopy (EDS) analysis showed that the metal ion (copper) was not detected in the treated zeolite and only absorbed by the biomass. Therefore, they concluded that zeolite had functioned as a support for the biomass [78]. There is a prominent challenge in water stream treatment which is faced with a presence of a number of metal ions in real samples. If there is any competition between them and a special removal of the adsorbent, it is an interesting issue to discuss among researchers. Figueroa-Torres et al. 2016 reported that although the predicted amount for the maximum biosorption capacity of copper raised from 28.23 in a single system to $35.46 \mathrm{mg} / \mathrm{g} \mathrm{SSV}$ in a binary system, the presence of both ions (copper and iron coexistence) in the medium diminished the actual biosorption capacity of biomass [48]. The mechanism of metal ion sorption by zeolite-immobilized biomass can be represented by some isotherm models, including Langmuir [5, 48], Sips [5], and Toth [5], and kinetic models such as the pseudo second-order type reaction $[48,52]$. Consequently, zeolite-immobilized biomass can be considered as a promising low-cost biosorbent for metal ion removal [48].

3.2.3. Nonmetal Removal. The zeolite-immobilized biomass also can be applied in the removal of nonmetals such as phosphorus and ammonium from aqueous solutions. Various factors are interfering in the cell immobilization and adsorption capacity such as carrier particle size, surface charge, and surface modification $[51,77,79,80]$. Hrenovic et al. 


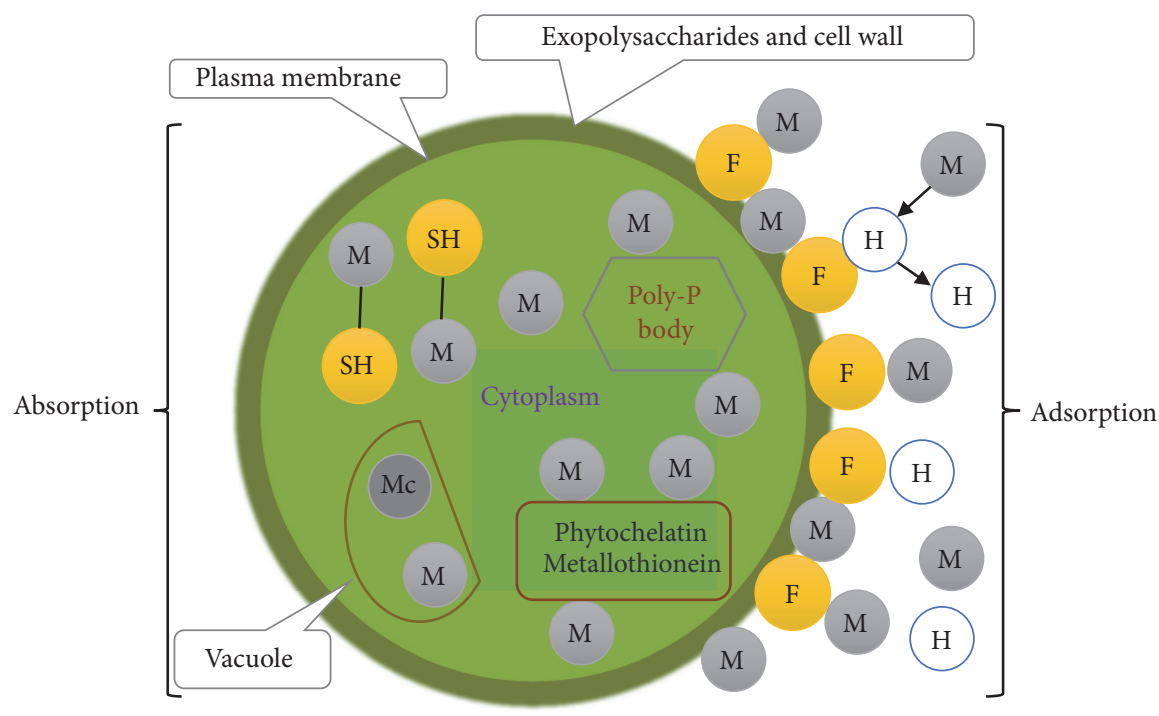

FIGURE 2: The process of metal sorption by living algal cells: M: metal ions, Mc: metal ion complex, F: functional groups, H: hydrogen ion, SH: sulphydryl (adapted from $[17,95,99])$.

2009 found that the number of immobilized cells correlated negatively with the size of support [77]. Also, Mery et al. 2012 studied the effect of zeolite particle size $(0.5,1.0$ and $2.0 \mathrm{~mm}$ ) on adherence of microorganism and adsorption capacity of ammonium, and their results showed that the greatest amount of zeolite adhered biomass was achieved for a particle size of $1 \mathrm{~mm}$ whereas the highest adsorption capacity of ammonium was obtained in a size of $0.5 \mathrm{~mm}$ [51]. As it mentioned, other factors influencing the adsorption of the microorganism in immobilization and adsorption capacity are the surface charge (defined by zeta potential) of both support and microorganism [77] and surface modification [80]. Hrenovic et al. 2009 reported that the increase of the zeta potential of supports correlated negatively with the number of immobilized cells [77]. Also, surfactant-modified zeolites (SMZ) were used as a support for Orthophosphate (p)accumulating bacteria to remove phosphorus from wastewater. According to the results, zeolite surface modification concluded in the change of the zeta potential of particles (from negative to positive) and improvement in adsorption capacity [80].

\section{Algal Immobilization}

4.1. Algae. One of the most famous photosynthetic organisms that are capable of living and growing in many different environmental conditions is algae [81]. Instead of using bacteria to treat wastewater, it is also possible to use algae due to the existing nutrient sources present in wastewater such as nitrates and phosphates. Algae can uptake those nutrients and use them for their cell growth [82]. Most of the researchers in the area of biotechnology prefer to work on algae because of their advantages such as producing biomass without needing many resources, increasing the level of oxygen in water effluents, reducing the level of carbon dioxide, and reaching lower operational costs [3]. Based on morphology and size, algae are classified into two groups: macro and micro. Macroalgae (or seaweed) are composed of multiple cells and divided into three groups of brown, green, and red based on their pigmentation. Microalgae are unicellular and classified into three most important groups: diatoms, green, and golden [83]. Algal biomass can be used in various applications, including production of primary and secondary metabolites for food, cosmetic and pharmaceutical industries $[3,14,58,84]$, biofuel and bioenergy $[3,14,84-$ 87], wastewater treatment process [3, 14, 82, 84, 88-101], animal feedstock enhancer [81], and agriculture purposes $[3,14,94]$. One of the significant applications of algae is in the bioremediation area. Various species of microalgae, including eukaryotic and prokaryotic and also their inactive forms, can be used for the bioremediation of metal ions [99]. They can be considered as suitable biosorbents due to some characteristics such as their abundance in seawater and fresh water, high metal sorption capacities, reusability, and cost-effectiveness [96]. Microalgae have been reported to have higher metal ions biosorption capacity than other microorganisms like fungi, cyanobacteria, and bacteria $[3,102,103]$. This is due to the fact that the algal cell wall has a number of functional groups such as amino $\left(-\mathrm{NH}_{2}\right)$, hydroxyl $(-\mathrm{OH})$, carboxyl (- $\mathrm{COOH})$, phosphoryl $\left(-\mathrm{PO}_{3} \mathrm{O}_{2}\right)$, sulphydryl $(-\mathrm{SH})$, etc. that are mostly responsible for metal ions biosorption [82, 88, 95, 98]. As shown in Figure 2, the process of metal uptake by microalgae can be explained in two ways: the first step is rapid adsorption onto the surface of the cell, and the second step is via the absorption or intracellular uptake that is dependent on cell metabolism [82, 95]. The process of metal ion adsorption includes their binding on the cell wall, cytoplasmic membrane, capsule substances, and extracellular compounds (external polysaccharides) [13, 95] whereas the process of metal ion absorption includes binding to phytochelatins, metallothioneins, cytoplasmic ligands, etc. [95]. 
4.2. Immobilization of Algal Biomass and Its Applications. Harvesting algal biomass from water streams, either culture medium or treated wastewater, is one of the most important challenges especially in a large-scale application. Harvesting methods such as mechanical, electrical, chemical, and biological techniques are not preferable due to the high assumption of chemicals and energy [100]. Immobilization of algae can be an alternative method to overcome the issues [100]. The immobilization of algae has been started over 40 years ago $[4,59]$. The advantages of immobilization are shown in Table 1 . The algal immobilization can provide high-value algal biomass $[3,14]$ which is different than the suspended one in the content and composition of lipid/chlorophyll, cell size, surface charge, protein content, and molecular compositions [104]. Zeng et al. 2013 studied the Chlorella sp. immobilization within a polymeric carrier and found that the immobilized cells achieved a total lipid and chlorophyll content of $14.85 \%$ and $3.36 \%$, respectively, which was higher than suspended ones [104]. In addition, Zeng et al. 2013 reported that although the microalgae cell growth in immobilized cultivation was slower than the suspended cells (due to their mass transfer problems), the capsule-immobilized microalgae had a systematic growth of the algal cells [105]. The similar finding was achieved by Mallick et al. 1994 who worked on the immobilization of Anabaena doliolum and Chlorella vulgaris and their results revealed that the agar-immobilized cells had a slow growth rate [106]. Furthermore, algal immobilization can increase the biosorption capacity and biomass activity as well [3]. The ability of microalgae in the attachment process depends on various factors, which are the age of microalgae whether it is in the exponential growth phase or in the stationary phase, culture state, and composition of the culture medium [13]. Furthermore, other important factors that influence the algal immobilization are the cell wall composition and surface charge of cells and carrier [107]. Eroglu et al. 2012 used chitosan nanofiber mats for the immobilization of Chlorella vulgaris. They reported that microalgae cell walls consisted of various polysaccharides compatible with the support surface and also Chlorella cells surface has a negative surface charge (related to uronic acid and/or sulfate groups) that makes an electrostatic attraction to chitosan with the positive charge (resulting from primary amine groups) [107]. In the case of immobilization support, natural biopolymers and synthetic compounds (e.g., alginate, carrageenan, agar, polyacrylamide, polypropylene, and silica gel) have been used for the algal immobilization [13, 17, 95]. Researchers often prefer to use natural polymers due to their low toxicity [17]. Among natural polymers, alginate [3, 13, 17, $102,108]$ and carrageenan $[3,13]$ have been widely used for the algal immobilization. On the other hand, polyacrylamide [17, $109,110]$ has been extensively used as a synthetic polymer due to the fact that it is more resistant than the natural polymers [17]. Also, some researchers have used other supports such as loofa sponge, chitosan, and polymer carriers [104, 106, 107, 111]. Akhtar et al. 2004 found that loofa sponge was an effective support for the entrapment of microalgae [111]. Also, Mallick et al. 1994 reported that the immobilization on chitosan was more efficient than other beads like agar, alginate, and carrageenan [106]. In addition, Eroglu et al. 2012 reported that chitosan nanofiber mat can be used as a waterinsoluble and nontoxic support for algae [107]. Zeng et al. 2013 used sodium cellulose sulphate/poly-dimethyl-diallylammonium chloride (NaCS-PDMDAAC) capsule for the immobilization of Chlorella sp. and their results showed that the immobilized cells had a robust morphology [104]. Table 4 lists various supports for algal immobilization. Immobilized microalgae can be harvested and converted to produce a variety of applications, including biofuel $[3,13,58]$, removal of BOD, COD [112, 113], metal ions [14, 95, 102, 106, 108, 109 , 111, 113-124], nonmetals [3, 11, 14, 106, 107, 112, 113, 119, 125-131], and use as a biosensor to measure the degree of water pollution $[13,14]$, toxicity of substances, and effluents in electronic devices [58] and as photosynthetic solar cells [132]. Table 4 summarizes the related researches on algal immobilization.

4.2.1. Production of High-Value Metabolites. Immobilized algae can be applied to the production of valuable metabolites. Desmet et al. 2015 synthesized a robust (Ca-alginate$\mathrm{SiO}_{2}$-polycation) shell: (Na-alginate- $\mathrm{SiO}_{2}$ ) core hybrid system for use in an encapsulation of Dunaliella tertiolecta. They reported that high photosynthetic activity was achieved over a long time (more than one year). The system can be applied in harvesting high-value compounds, producing biofuel cells to photosynthetic solar cells for production of electricity, energy transformation, etc. [132].

4.2.2. Removal of Nitrate and Phosphate. Nutrient removal, including nitrate and phosphate, is another application of immobilized algae [11, 107]. Eroglu et al. 2012 used chitosan nanofiber mats immobilized Chlorella vulgaris to remove nitrate from liquid effluents. They reported that around 30 $\%$ of initial nitrate value was diminished within the first two days by chitosan uptake (physicochemical adsorption) and, after that, the remaining nitrate uptake continued with the growth of algae using it for its cellular metabolism. Their results also showed the overall removal rate of $32 \pm$ $3 \%$ for Chlorella-absent and $87 \pm 4 \%$ for Chlorella-attached chitosan mats [107]. Zeng et al. 2012 used Chlorella sp. and entrapped the cells in a polymer carrier of sodium cellulose sulphate/poly-dimethyl-diallyl-ammonium chloride (NaCSPDMDAAC) to make algal capsules for the removal of total nitrogen (T-N) and phosphate $\left(\mathrm{PO}_{4}{ }^{3-}-\mathrm{P}\right)$ from artificial wastewater. Their results showed that high removal rate of $12.56 \mathrm{mg} / \mathrm{g}$ biomass per day for T-N and $10.24 \mathrm{mg} / \mathrm{g}$ biomass per day for $\mathrm{PO}_{4}{ }^{3-}-\mathrm{P}$ was achieved at the end of the treatment process [11].

4.2.3. Removal of Metal Ions. The amount of metal ion uptake in suspended and immobilized algal systems is different. On the one hand, the biosorption capacity of immobilized systems is higher than the suspended one and on the other hand, the number of repetitions in immobilized cells makes the researchers shift from the suspended to the immobilized one in the removal of metal ions [111, 117, 124]. Nasreen et al. 2008 used Chlorella sorokiniana for immobilization in loofa sponge as a biosorbent for the removal of $\mathrm{Cr}$ (III) 
TABLE 4: Various types of immobilized microalgae and their applications.

\begin{tabular}{|c|c|c|c|c|}
\hline $\begin{array}{l}\text { Microalgae } \\
\text { strain }\end{array}$ & Kind of support & Applications & Findings & References \\
\hline $\begin{array}{l}\text { Chlorella } \\
\text { vulgaris }\end{array}$ & $\begin{array}{c}\text { Chitosan nanofiber } \\
\text { mats }\end{array}$ & Nitrate removal & Around 87\% removal & {$[107]$} \\
\hline Chlorella sp. & $\begin{array}{l}\text { Sodium alginate } \\
\text { beads }\end{array}$ & $\begin{array}{l}\text { Copper and zinc } \\
\text { removal }\end{array}$ & $\begin{array}{l}\text { Biosorption capacity } \\
\text { of } 33.4 \text { for copper and } \\
28.5 \mathrm{mg} / \mathrm{g} \text { for zinc }\end{array}$ & {$[123]$} \\
\hline Chlorella sp. & NaCS-PDMDAAC & $\begin{array}{l}\text { Total nitrogen }(\mathrm{T}-\mathrm{N}) \\
\text { and phosphate }\left(\mathrm{PO}_{4}{ }^{3-}\right. \\
-\mathrm{P})\end{array}$ & $\begin{array}{l}\text { Removal rate of } 12.56 \\
\text { for T-N and } 10.24 \\
\mathrm{mg} / \mathrm{g} \text { biomass per day } \\
\text { for } \mathrm{PO}_{4}{ }^{3-}-\mathrm{P}\end{array}$ & {$[11]$} \\
\hline $\begin{array}{l}\text { Scenedesmus } \\
\text { quadricauda }\end{array}$ & Ca-alginate beads & $\begin{array}{l}\text { Removal of } \mathrm{Cu}(\mathrm{II}) \text {, } \\
\mathrm{Zn}(\mathrm{II}) \text { and } \mathrm{Ni}(\mathrm{II})\end{array}$ & $\begin{array}{c}\text { Maximum adsorption } \\
\text { capacity of } 75.6,55.2 \\
\text { and } 30.4 \mathrm{mg} / \mathrm{g} \text { for } \\
\mathrm{Cu}(\mathrm{II}), \mathrm{Zn}(\mathrm{II}) \text { and } \\
\mathrm{Ni}(\mathrm{II})\end{array}$ & {$[108]$} \\
\hline Scenedesmus sp. & Chitosan & $\begin{array}{l}\text { Removal of nitrate } \\
\text { and phosphate }\end{array}$ & $\begin{array}{c}70 \% \text { nitrate and } 94 \% \\
\text { phosphate removal }\end{array}$ & {$[131]$} \\
\hline $\begin{array}{l}\text { Chlorella } \\
\text { sorokiniana }\end{array}$ & Loofa sponge & Removal of $\mathrm{Cr}$ (III) & $\begin{array}{c}\text { Maximum } \\
\text { biosorption capacity } \\
\text { of } 69.26 \mathrm{mg} \mathrm{Cr}(\mathrm{III}) / \mathrm{g} \\
\text { biosorbent }\end{array}$ & {$[124]$} \\
\hline $\begin{array}{l}\text { Chlorella } \\
\text { vulgaris and } \\
\text { Scenedesmus } \\
\text { rubescens }\end{array}$ & $\begin{array}{c}\text { The twin-layer } \\
\text { system }\end{array}$ & $\begin{array}{l}\text { Removal of nitrogen } \\
\text { and phosphorus }\end{array}$ & $\begin{array}{l}\text { Removal to less than } \\
10 \% \text { of the initial } \\
\text { concentration }\end{array}$ & {$[125]$} \\
\hline Tetraselmis chui & Calcium alginate & $\begin{array}{c}\text { Removal of } \mathrm{Cu} \text { and } \\
\mathrm{Cd}\end{array}$ & $\begin{array}{l}\text { Removal of all } \mathrm{Cu} \text { and } \\
\text { removal of around } \\
20 \% \text { of total Cd }\end{array}$ & {$[115]$} \\
\hline $\begin{array}{l}\text { Scenedesmus } \\
\text { intermedius } \\
\text { Chod. and } \\
\text { Nannochloris sp. }\end{array}$ & $\begin{array}{c}\text { Calcium alginate } \\
\text { beads }\end{array}$ & $\begin{array}{l}\text { Phosphorus }(\mathrm{P}) \text { and } \\
\text { nitrogen }(\mathrm{N}) \text { uptake }\end{array}$ & $\begin{array}{l}0.012 \mathrm{mg} \mathrm{P} \mathrm{h}^{-1} \text { and } \\
0.009 \mathrm{mg} \mathrm{N} \mathrm{h}^{-1} \text { for } \\
\text { Scenedesmus } \\
\text { intermedius and } \\
0.009 \mathrm{mg} \mathrm{P} \mathrm{h}^{-1} \text { and } \\
0.006 \mathrm{mg} \mathrm{N} \mathrm{h}^{-1} \text { for } \\
\text { Nannochloris sp. }\end{array}$ & {$[127]$} \\
\hline $\begin{array}{l}\text { Chlorella } \\
\text { sorokiniana }\end{array}$ & Loofa sponge & $\begin{array}{c}\text { The removal of } \\
\text { nickel(II) }\end{array}$ & $\begin{array}{c}\text { Biosorption capacity } \\
\text { of } 60.38 \mathrm{mg} \\
\text { nickel(II)/g }\end{array}$ & {$[111]$} \\
\hline $\begin{array}{l}\text { Trentepohlia } \\
\text { aurea }\end{array}$ & Filter paper & $\begin{array}{c}\text { Removal of inorganic } \\
\text { nitrogen sources }\end{array}$ & $\begin{array}{l}\text { The removal rate of } \\
\text { total inorganic } \mathrm{N} \text { ion } \\
\text { of } 5.11 \mathrm{mg} \mathrm{N}^{-1} \text { day }^{-1}\end{array}$ & {$[128]$} \\
\hline $\begin{array}{l}\text { Chlorella } \\
\text { sorokiniana }\end{array}$ & $\begin{array}{l}\text { Vegetable sponge } \\
\text { of Luffa cylindrica }\end{array}$ & Cadmium removal & $\begin{array}{l}\text { The cadmium } \\
\text { sorption capacity of } \\
192 \mathrm{mg} / \mathrm{g}\end{array}$ & {$[116]$} \\
\hline $\begin{array}{l}\text { Chlorella } \\
\text { sorokiniana }\end{array}$ & Luffa sponge discs & Removal of $\mathrm{Ni}(\mathrm{II})$ & $\begin{array}{l}\text { The removal of } 97 \% \text { of } \\
\text { equilibrium loading }\end{array}$ & {$[117]$} \\
\hline $\begin{array}{l}\text { Chlorella } \\
\text { vulgaris }\end{array}$ & $\begin{array}{c}\text { Calcium alginate } \\
\text { beads }\end{array}$ & Removal of $\mathrm{N}$ and $\mathrm{P}$ & $\begin{array}{c}100 \% \text { removal of } \\
\mathrm{NH}_{4}^{+}-\mathrm{N} \text { and around } \\
95 \% \text { reduction of } \\
\mathrm{PO}_{4}{ }^{3-}-\mathrm{P}\end{array}$ & [129] \\
\hline $\begin{array}{l}\text { Chlorella } \\
\text { homosphaera }\end{array}$ & Sodium alginate & $\begin{array}{c}\text { Biosorption of } \\
\text { cadmium, zinc and } \\
\text { gold }\end{array}$ & $\begin{array}{l}\text { Near } 100 \% \text { metal } \\
\text { removal for cadmium } \\
\text { and zinc and } 90 \% \\
\text { removal of gold }\end{array}$ & {$[121]$} \\
\hline
\end{tabular}


from an aqueous solution. Their results showed a higher increase in uptake of chromium (17.79\%) for the immobilized biomass than the suspended one [124]. Akhtar et al. 2004 applied the same immobilized system for the removal of nickel(II) and their result revealed a significant increase of $25.3 \%$ in biosorption capacity compared to the suspended one [111]. Furthermore, Nasreen et al. 2008 and Akhtar et al. 2004 and 2003 reported that this immobilization system showed an excellent physicochemical stability without any significant release of algae in nickel(II) removal and it has a potential to be used for 5 and 7 cycles with a little decrease in metal uptake capacity $[111,117,124]$. According to Wan Maznah et al. 2012 and Bayramoglu and Arica 2009, the main mechanism in the biosorption process of immobilized microalgae is an adsorption in the form of physical and ion exchange interactions $[108,123]$. In the biosorption process of immobilized microalgae, some operational parameters interfere and give an impact to the biosorption capacity, including $\mathrm{pH}$, biosorbent concentration, the initial concentration of metal ions, time, and temperature $[102,108,111,119,123,124]$. The $\mathrm{pH}$ of the solution is one of the most important factors in biosorption as it affects the metal ion speciation and the surface charge of the hybrid biosorbent [108]. According to researchers, the range of $\mathrm{pH}$ for the maximum biosorption was around 4 to $8.0[102,108,111,119,124]$. The low metal ion biosorption at low amounts of $\mathrm{pH}$ is related to the competition between metal ions and protons for binding sites and at a high amount of $\mathrm{pH}$ is related to the decreased solubility of metal ions [124]. The biosorbent concentration is another significant factor affecting biosorption capacity. Akhtar et al. 2004 used Chlorella sorokiniana for immobilization on loofa sponge for the removal of nickel(II). They reached an increase in metal ion uptake with an increase in immobilized biomass concentration up to $2.5 \mathrm{~g} / \mathrm{L}$ [111]. As a matter of fact, cell immobilization permits little or no interaction with the rest of immobilized cells and does not let cells clump; hence, the binding sites available on the cell wall have maximum accessibility to metal ions [111]. According to the findings of researchers, initial metal ion concentration is another operational parameter that can have an effect on the growth of algae, cell count, chlorophyll content, and adsorption capacity [123]. Wan Maznah et al. 2012 used Chlorella sp. and Chlamydomonas sp. as biomass for the immobilization in sodium alginate beads to remove copper and zinc. The results of the biosorption capacity of Chlorella sp. of 33.4 and $28.5 \mathrm{mg} / \mathrm{g}$ were achieved after 6 hours for copper and zinc, respectively. They reported that metal ions affected the growth of algae at a concentration of $5 \mathrm{mg} / \mathrm{L}$ leading to significant diminishment in the cell count and contents of chlorophyll $\mathrm{a}$ and $\mathrm{b}$ for microalgae [123]. In the case of metal ion removal by immobilized microalgae, many researchers reported that the adsorption can improve when the initial metal ions concentration increases up to 200 , 500 , or $600 \mathrm{mg} / \mathrm{L}$ in the medium $[102,108,111]$. Also, time and temperature are other factors during algal immobilization. A study conducted by the researchers showed that the kinetics of metal ion biosorption by immobilized cells was rapid in the first $5 \mathrm{~min}[117,124]$ and can reach up to an equilibrium in 15 or 60 min $[102,111,117,124]$ and after that available sites on biosorbent were a limiting factor [124]. Bayramoǧlu et al. 2006 considered the temperature range from 5 to $40^{\circ} \mathrm{C}$ in biosorption process but they did not observe any effect on the adsorption capacity of immobilized cells (Chlamydomonas reinhardtii in $\mathrm{Ca}$-alginate), and they reported that an adsorption of metal ions was temperature independent [102]. In case of immobilized algae, the biosorption equilibrium can be represented by Langmuir [102, 108, 111, 124], Freundlich [102, 108, 111], and Dubinin-Radushkevich isotherm [108] models and the biosorption kinetics follow the second [108] and pseudo-second [124] order kinetic models.

\section{The Potential Application of Zeolite as an Ideal Carrier for Algal Immobilization}

One of the most significant drawbacks in algal immobilization is finding a suitable carrier. Natural carriers such as carrageenan and alginate have the problem of low stability [13] and synthetic polymers such as polyacrylamide face the drawbacks of high cost and toxicity to living cells [17]. Although the researchers have tried many materials as a support such as loofa sponge, chitosan, and polymer carriers $[104,106,107,111]$, many works need to be done to prove its feasibility. The ideal carrier for the algal immobilization must fulfill some requirements such as nontoxicity, cheapness, acceptable process efficiency, being potential to reuse, and stability. However, it seems that reaching these aims and finding an excellent carrier with these characteristics need further researches and remain a challenge. One of the materials as a suitable candidate for algal immobilization is zeolite. As mentioned in this paper, to date, various types of zeolite have been successfully used for the immobilization of bacteria and yeast. If there is any possibility to apply them as a carrier for the immobilization of different types of algae, it needs to be researched. In case of successful immobilization, one of the most important applications of the bioparticle (i.e., zeoliteimmobilized algae) can be in the biosorption process of metal ions in which zeolite acts as a carrier and probably contributes to the sorption process resulting in improved efficiency. All these possibilities need to be studied and justified in the future.

\section{Conflicts of Interest}

The authors declare that there are no conflicts of interest regarding the publication of this paper.

\section{Acknowledgments}

The authors would like to appreciate the Department of Chemical and Environmental Engineering of Universiti Putra Malaysia (UPM) for providing suitable research facilities.

\section{References}

[1] V. J. Inglezakis, M. D. Loizidou, and H. P. Grigoropoulou, "Ion exchange of $\mathrm{Pb} 2+, \mathrm{Cu} 2+, \mathrm{Fe} 3+$, and $\mathrm{Cr} 3+$ on natural clinoptilolite: Selectivity determination and influence of acidity on metal uptake," Journal of Colloid and Interface Science, vol. 261, no. 1, pp. 49-54, 2003. 
[2] G. F. Kwakye, R. A. McMinimy, and M. Aschner, "DiseaseToxicant Interactions in Parkinson's Disease Neuropathology," Neurochemical Research, vol. 42, no. 6, pp. 1772-1786, 2017.

[3] E. Eroglu, S. M. Smith, and C. L. Raston, "Application of Various Immobilization Techniques for Algal Bioprocesses," in Biomass and Biofuels from Microalgae, vol. 2 of Biofuel and Biorefinery Technologies, pp. 19-44, Springer International Publishing, Cham, 2015.

[4] M. Das and A. Adholeya, "Potential uses of immobilized bacteria, fungi, algae, and their aggregates for treatment of organic and inorganic pollutants in wastewater," in Water Challenges and Solutions on a Global Scale, vol. 1206 of ACS Symposium Series, pp. 319-337, American Chemical Society, Washington, DC, USA, 2015.

[5] C. Quintelas, Z. Rocha, B. Silva, B. Fonseca, H. Figueiredo, and T. Tavares, "Biosorptive performance of an Escherichia coli biofilm supported on zeolite $\mathrm{NaY}$ for the removal of $\mathrm{Cr}(\mathrm{VI})$, $\mathrm{Cd}(\mathrm{II}), \mathrm{Fe}(\mathrm{III})$ and $\mathrm{Ni}(\mathrm{II})$," Chemical Engineering Journal, vol. 152, no. 1, pp. 110-115, 2009.

[6] K. K. Krishnani, X. Meng, C. Christodoulatos, and V. M. Boddu, "Biosorption mechanism of nine different heavy metals onto biomatrix from rice husk," Journal of Hazardous Materials, vol. 153, no. 3, pp. 1222-1234, 2008.

[7] N. Abdel-Raouf, A. A. Al-Homaidan, and I. B. M. Ibraheem, "Microalgae and wastewater treatment," Saudi Journal of Biological Sciences, vol. 19, no. 3, pp. 257-275, 2012.

[8] M. Aziz and W. Ng, "Feasibility of wastewater treatment using the activated-algae process," Bioresource Technology, vol. 40, no. 3, pp. 205-208, 1992.

[9] S.-M. Phang and O. Kim-Chong, "Algal biomass production in digested palm oil mill effluent," Biological Wastes, vol. 25, no. 3, pp. 177-191, 1988.

[10] E. B. Sydney, T. E. da Silva, A. Tokarski et al., "Screening of microalgae with potential for biodiesel production and nutrient removal from treated domestic sewage," Applied Energy, vol. 88, no. 10, pp. 3291-3294, 2011.

[11] X. Zeng, M. K. Danquah, C. Zheng, R. Potumarthi, X. D. Chen, and Y. Lu, "NaCS-PDMDAAC immobilized autotrophic cultivation of Chlorella sp. for wastewater nitrogen and phosphate removal," Chemical Engineering Journal, vol. 187, pp. 185-192, 2012.

[12] X. Zeng, M. K. Danquah, X. D. Chen, and Y. Lu, "Microalgae bioengineering: From CO2 fixation to biofuel production," Renewable \& Sustainable Energy Reviews, vol. 15, no. 6, pp. 32523260, 2011.

[13] S. G. Vasilieva, E. S. Lobakova, A. A. Lukyanov, and A. E. Solovchenko, "Immobilized microalgae in biotechnology," Moscow University Biological Sciences Bulletin, vol. 71, no. 3, pp. 170-176, 2016.

[14] N. Malik, "Biotechnological potential of immobilised algae for wastewater N, P and metal removal: a review," BioMetals, vol. 15, pp. 377-390, 2002.

[15] A. P. Djukić-Vuković, B. M. Jokić, S. D. Kocić-Tanackov, J. D. Pejin, and L. V. Mojović, "Mg-modified zeolite as a carrier for Lactobacillus rhamnosus in $\mathrm{L}(+)$ lactic acid production on distillery wastewater," Journal of the Taiwan Institute of Chemical Engineers, vol. 59, pp. 262-266, 2016.

[16] A. Idris and W. Suzana, "Effect of sodium alginate concentration, bead diameter, initial $\mathrm{pH}$ and temperature on lactic acid production from pineapple waste using immobilized Lactobacillus delbrueckii," Process Biochemistry, vol. 41, no. 5, pp. 1117-1123, 2006.
[17] A. K. Zeraatkar, H. Ahmadzadeh, A. F. Talebi, N. R. Moheimani, and M. P. McHenry, "Potential use of algae for heavy metal bioremediation, a critical review," Journal of Environmental Management, vol. 181, no. 1, pp. 817-831, 2016.

[18] T. An, L. Zhou, G. Li, J. Fu, and G. Sheng, "Recent patents on immobilized microorganism technology and its engineering application in wastewater treatment," Recent Patents on Engineering, vol. 2, no. 1, pp. 28-35, 2008.

[19] M. S. Jami, N.-S. Rosli, and M. K. Amosa, "Optimization of manganese reduction in biotreated POME onto $3 \mathrm{~A}$ molecular sieve and clinoptilolite zeolites," Water Environment Research, vol. 88, no. 6, pp. 566-576, 2016.

[20] U. Wingenfelder, C. Hansen, G. Furrer, and R. Schulin, "Removal of heavy metals from mine waters by natural zeolites," Environmental Science \& Technology, vol. 39, no. 12, pp. 46064613, 2005.

[21] E. Erdem, N. Karapinar, and R. Donat, "The removal of heavy metal cations by natural zeolites," Journal of Colloid and Interface Science, vol. 280, no. 2, pp. 309-314, 2004.

[22] S. K. Pitcher, R. C. T. Slade, and N. I. Ward, "Heavy metal removal from motorway stormwater using zeolites," Science of the Total Environment, vol. 334-335, pp. 161-166, 2004.

[23] S. Babel and T. A. Kurniawan, "Low-cost adsorbents for heavy metals uptake from contaminated water: a review," Journal of Hazardous Materials, vol. 97, no. 1-3, pp. 219-243, 2003.

[24] M. Vaca Mier, R. López Callejas, R. Gehr, B. E. Jiménez Cisneros, and P. J. J. Alvarez, "Heavy metal removal with mexican clinoptilolite: Multi-component ionic exchange," Water Research, vol. 35, no. 2, pp. 373-378, 2001.

[25] S. K. Ouki and M. Kavannagh, "Treatment of metalscontaminated wastewaters by use of natural zeolites," Water Science and Technology, vol. 39, no. 10-11, pp. 115-122, 1999.

[26] M. J. zamzow, B. R. Eichbaum, K. R. Sandgren, and D. E. Shanks, "Removal of heavy metals and other cations from wastewater using zeolites," Separation Science and Technology, vol. 25, no. 13-15, pp. 1555-1569, 1990.

[27] G. Blanchard, M. Maunaye, and G. Martin, "Removal of heavy metals from waters by means of natural zeolites," Water Research, vol. 18, no. 12, pp. 1501-1507, 1984.

[28] N. H. Mthombeni, M. S. Onyango, and O. Aoyi, "Adsorption of hexavalent chromium onto magnetic natural zeolite-polymer composite," Journal of the Taiwan Institute of Chemical Engineers, vol. 50, pp. 242-251, 2015.

[29] H. Liu, S. Peng, L. Shu, T. Chen, T. Bao, and R. L. Frost, "Magnetic zeolite NaA: synthesis, characterization based on metakaolin and its application for the removal of $\mathrm{Cu}^{2+}, \mathrm{Pb}^{2+}$," Chemosphere, vol. 91, no. 11, pp. 1539-1546, 2013.

[30] Z. Yuna, "Review of the natural, modified, and synthetic zeolites for heavy metals removal from wastewater," Environmental Engineering Science, vol. 33, no. 7, pp. 443-454, 2016.

[31] K. Barquist and S. C. Larsen, "Chromate adsorption on bifunctional, magnetic zeolite composites," Microporous and Mesoporous Materials, vol. 130, no. 1-3, pp. 197-202, 2010.

[32] L. C. A. Oliveira, D. I. Petkowicz, A. Smaniotto, and S. B. C. Pergher, "Magnetic zeolites: a new adsorbent for removal of metallic contaminants from water," Water Research, vol. 38, no. 17, pp. 3699-3704, 2004.

[33] P. Misaelides, "Application of natural zeolites in environmental remediation: A short review," Microporous and Mesoporous Materials, vol. 144, no. 1-3, pp. 15-18, 2011. 
[34] S. K. Alpat, Ö. Özbayrak, Ş. Alpat, and H. Akçay, "The adsorption kinetics and removal of cationic dye, Toluidine Blue O, from aqueous solution with Turkish zeolite," Journal of Hazardous Materials, vol. 151, no. 1, pp. 213-220, 2008.

[35] S. E. Bailey, T. J. Olin, R. M. Bricka, and D. D. Adrian, "A review of potentially low-cost sorbents for heavy metals," Water Research, vol. 33, no. 11, pp. 2469-2479, 1999.

[36] H. Liu, S. Peng, L. Shu, T. Chen, T. Bao, and R. L. Frost, "Effect of Fe $3 \mathrm{O} 4$ addition on removal of ammonium by zeolite NaA," Journal of Colloid and Interface Science, vol. 390, no. 1, pp. 204210, 2013.

[37] T. Sugawara, Y. Matsuura, T. Anzai, and O. Miura, "Removal of Ammonia Nitrogen From Water by Magnetic Zeolite and HighGradient Magnetic Separation," IEEE Transactions on Applied Superconductivity, vol. 26, no. 4, pp. 1-4, 2016.

[38] S. Wang and Y. Peng, "Natural zeolites as effective adsorbents in water and wastewater treatment," Chemical Engineering Journal, vol. 156, no. 1, pp. 11-24, 2010.

[39] M. Zhao, Y. Xu, C. Zhang, H. Rong, and G. Zeng, "New trends in removing heavy metals from wastewater," Applied Microbiology and Biotechnology, vol. 100, no. 15, pp. 6509-6518, 2016.

[40] M. Madadi and R. Rahimi, "Zeolite-immobilized Mn(III), $\mathrm{Fe}(\mathrm{III})$ and $\mathrm{Co}(\mathrm{III})$ complexes with 5,10,15,20-tetra(4methoxyphenyl)porphyrin as heterogeneous catalysts for the epoxidation of (R)-(+)-limonene: Synthesis, characterization and catalytic activity," Reaction Kinetics, Mechanisms and Catalysis, vol. 107, no. 1, pp. 215-229, 2012.

[41] M. A. Shavandi, Z. Haddadian, M. H. S. Ismail, N. Abdullah, and Z. Z. Abidin, "Removal of Fe(III), Mn(II) and Zn(II) from palm oil mill effluent (POME) by natural zeolite," Journal of the Taiwan Institute of Chemical Engineers, vol. 43, no. 5, pp. 750759, 2012.

[42] M. A. Shavandi, Z. Haddadian, M. H. S. Ismail, and N. Abdullah, "Continuous metal and residual oil removal from palm oil mill effluent using natural zeolite-packed column," Journal of the Taiwan Institute of Chemical Engineers, vol. 43, no. 6, pp. 934941, 2012.

[43] T. Motsi, N. A. Rowson, and M. J. H. Simmons, "Adsorption of heavy metals from acid mine drainage by natural zeolite," International Journal of Mineral Processing, vol. 92, no. 1-2, pp. 42-48, 2009.

[44] P. Kosobucki, M. Kruk, and B. Buszewski, "Immobilization of selected heavy metals in sewage sludge by natural zeolites," Bioresource Technology, vol. 99, no. 13, pp. 5972-5976, 2008.

[45] M. K. Doula, "Removal of $\mathrm{Mn}^{2+}$ ions from drinking water by using Clinoptilolite and a Clinoptilolite-Fe oxide system," Water Research, vol. 40, no. 17, pp. 3167-3176, 2006.

[46] S. Shindo, S. Takata, H. Taguchi, and N. Yoshimura, "Development of novel carrier using natural zeolite and continuous ethanol fermentation with immobilized Saccharomyces cerevisiae in a bioreactor," Biotechnology Letters, vol. 23, no. 24, pp. 2001-2004, 2001.

[47] Z. Al-Hassan, V. Ivanova, E. Dobreva et al., "Non-porous magnetic supports for cell immobilization," Journal of Fermentation and Bioengineering, vol. 71, no. 2, pp. 114-117, 1991.

[48] G. M. Figueroa-Torres, M. T. Certucha-Barragán, E. AcedoFélix, O. Monge-Amaya, F. J. Almendariz-Tapia, and L. A. Gasca-Estefanía, "Kinetic studies of heavy metals biosorption by acidogenic biomass immobilized in clinoptilolite," Journal of the Taiwan Institute of Chemical Engineers, vol. 61, pp. 241-246, 2016.
[49] R. I. Corona-González, R. Miramontes-Murillo, E. ArriolaGuevara, G. Guatemala-Morales, G. Toriz, and C. Pelayo-Ortiz, "Immobilization of Actinobacillus succinogenes by adhesion or entrapment for the production of succinic acid," Bioresource Technology, vol. 164, pp. 113-118, 2014.

[50] A. P. Djukić-Vuković, L. V. Mojović, B. M. Jokić, S. B. Nikolić, and J. D. Pejin, "Lactic acid production on liquid distillery stillage by Lactobacillus rhamnosus immobilized onto zeolite," Bioresource Technology, vol. 135, pp. 454-458, 2013.

[51] C. Mery, L. Guerrero, J. Alonso-Gutiérrez et al., "Evaluation of natural zeolite as microorganism support medium in nitrifying batch reactors: Influence of zeolite particle size," Journal of Environmental Science and Health, Part A: Toxic/Hazardous Substances and Environmental Engineering, vol. 47, no. 3, pp. 420-427, 2012.

[52] M. Pazos, M. Branco, I. C. Neves, M. A. Sanromán, and T. Tavares, "Removal of $\mathrm{Cr}(\mathrm{VI})$ from aqueous solutions by a bacterial biofilm supported on zeolite: optimisation of the operational conditions and scale-up of the bioreactor," Chemical Engineering \& Technology, vol. 33, no. 12, pp. 2008-2014, 2010.

[53] S. Weiß, M. Tauber, W. Somitsch et al., "Enhancement of biogas production by addition of hemicellulolytic bacteria immobilised on activated zeolite," Water Research, vol. 44, no. 6, pp. 1970-1980, 2010.

[54] S. Lameiras, C. Quintelas, and T. Tavares, "Biosorption of $\mathrm{Cr}$ (VI) using a bacterial biofilm supported on granular activated carbon and on zeolite," Bioresource Technology, vol. 99, no. 4, pp. 801-806, 2008.

[55] N. Fernández, S. Montalvo, F. Fernández-Polanco et al., "Real evidence about zeolite as microorganisms immobilizer in anaerobic fluidized bed reactors," Process Biochemistry, vol. 42, no. 4, pp. 721-728, 2007.

[56] A. López, N. Lázaro, and A. M. Marqués, “The interphase technique: A simple method of cell immobilization in gelbeads," Journal of Microbiological Methods, vol. 30, no. 3, pp. 231-234, 1997.

[57] I. Moreno-Garrido, "Microalgae immobilization: current techniques and uses," Bioresource Technology, vol. 99, no. 10, pp. 3949-3964, 2008.

[58] J. Kaparapu, M. Narasimha, and R. Geddada, "Applications of immobilized algae," Journal of Algal Biomass Utilization, vol. 7, pp. 122-128, 2016.

[59] L. E. de-Bashan and Y. Bashan, "Immobilized microalgae for removing pollutants: Review of practical aspects," Bioresource Technology, vol. 101, no. 6, pp. 1611-1627, 2010.

[60] Y. Liu, M. H. Rafailovich, R. Malal, D. Cohn, and D. Chidambaram, "Engineering of bio-hybrid materials by electrospinning polymer-microbe fibers," Proceedings of the National Acadamy of Sciences of the United States of America, vol. 106, no. 34, pp. 14201-14206, 2009.

[61] E. J. T. M. Leenen, V. A. P. Dos Santos, K. C. F. Grolle, J. Tramper, and R. H. Wijffels, "Characteristics of and selection criteria for support materials for cell immobilization in wastewater treatment," Water Research, vol. 30, no. 12, pp. 2985-2996, 1996.

[62] M. B. Cassidy, H. Lee, and J. T. Trevors, "Environmental applications of immobilized microbial cells: A review," Journal of Industrial Microbiology and Biotechnology, vol. 16, no. 2, pp. 79-101, 1996.

[63] A. Macario, G. Giordano, L. Setti et al., "Study of lipase immobilization on zeolitic support and transesterification reaction in a solvent free-system," Journal of Biocatalysis \& Biotransformation, vol. 25, no. 2-4, pp. 328-335, 2007. 
[64] B. Godlewska-Żyłkiewicz, "Biosorption of platinum and palladium for their separation/preconcentration prior to graphite furnace atomic absorption spectrometric determination," Spectrochimica Acta Part B: Atomic Spectroscopy, vol. 58, no. 8, pp. 1531-1540, 2003.

[65] M. S. Abdel Hameed and O. H. Ebrahim, "Biotechnological potential uses of immobilized algae," International Journal of Agriculture and Biology, vol. 9, pp. 183-192, 2007.

[66] J. Hrenovic, D. Kovacevic, T. Ivankovic, and D. Tibljas, "Selective immobilization of Acinetobacter junii on the natural zeolitized tuff in municipal wastewater," Colloids and Surfaces B: Biointerfaces, vol. 88, no. 1, pp. 208-214, 2011.

[67] D. R. Durham, L. C. Marshall, J. G. Miller, and A. B. Chmurny, "New composite biocarriers engineered to contain adsorptive and ion- exchange properties improve immobilized-cell bioreactor process dependability," Applied and Environmental Microbiology, vol. 60, no. 11, pp. 4178-4181, 1994.

[68] W. J. Thomas and B. D. Crittenden, Adsorption Technology and Design, Butterworth-Heinemann, Oxford, Boston, 1998.

[69] K. Margeta, N. Z. Logar, M. iljeg, and A. Farka, "Natural Zeolites in Water Treatment - How Effective is Their Use," in Water Treatment, W. Elshorbagy, Ed., InTech, 2013.

[70] M. Kubota, T. Nakabayashi, Y. Matsumoto et al., "Selective adsorption of bacterial cells onto zeolites," Colloids and Surfaces B: Biointerfaces, vol. 64, no. 1, pp. 88-97, 2008.

[71] Z. Milán, P. Villa, E. Sánchez et al., "Effect of natural and modified zeolite addition on anaerobic digestion of piggery waste," Water Science and Technology, vol. 48, no. 6, pp. 263269, 2003.

[72] S. Weiß, M. Lebuhn, D. Andrade et al., "Activated zeolite Suitable carriers for microorganisms in anaerobic digestion processes?" Applied Microbiology and Biotechnology, vol. 97, no. 7, pp. 3225-3238, 2013.

[73] S. Badel, T. Bernardi, and P. Michaud, "New perspectives for Lactobacilli exopolysaccharides," Biotechnology Advances, vol. 29, no. 1, pp. 54-66, 2011.

[74] Y. Wu, T. Li, and L. Yang, "Mechanisms of removing pollutants from aqueous solutions by microorganisms and their aggregates: A review," Bioresource Technology, vol. 107, pp. 10-18, 2012.

[75] S. S. Ahluwalia and D. Goyal, "Microbial and plant derived biomass for removal of heavy metals from wastewater," Bioresource Technology, vol. 98, no. 12, pp. 2243-2257, 2007.

[76] Z. Aksu, F. Gönen, and Z. Demircan, "Biosorption of chromium(VI) ions by Mowital ${ }^{\circledR} \mathrm{B} 30 \mathrm{H}$ resin immobilized activated sludge in a packed bed: Comparison with granular activated carbon," Process Biochemistry, vol. 38, no. 2, pp. 175186, 2002.

[77] J. Hrenovic, T. Ivankovic, and D. Tibljas, "The effect of mineral carrier composition on phosphate-accumulating bacteria immobilization," Journal of Hazardous Materials, vol. 166, no. 2-3, pp. 1377-1382, 2009.

[78] O. Monge-Amaya, J. L. Valenzuela-García, E. A. Félix, M. T. Certucha-Barragán, A. L. Leal-Cruz, and F. J. AlmendarizTapia, "Biosorptive behavior of aerobic biomass biofilm supported on clinoptilolite zeolite for the removal of copper," Mineral Processing and Extractive Metallurgy, vol. 34, no. 6, pp. 422-428, 2013.

[79] A. Hedström and L. R. Amofah, "Adsorption and desorption of ammonium by clinoptilolite adsorbent in municipal wastewater treatment systems," Journal of Environmental Engineering and Science, vol. 7, no. 1, pp. 53-61, 2008.
[80] J. Hrenovic, M. Rozic, L. Sekovanic, and A. Anic-Vucinic, "Interaction of surfactant-modified zeolites and phosphate accumulating bacteria," Journal of Hazardous Materials, vol. 156, no. 1-3, pp. 576-582, 2008.

[81] H. Kamyab, M. F. Md Din, C. Lee Tin et al., "Micro-macro algal mixture as a promising agent for treating POME discharge and its potential use as animal feed stock enhancer," Jurnal Teknologi, vol. 68, no. 5, 2014.

[82] S. Dwivedi, "Bioremediation of heavy metal by algae: current and future perspective," Journal of Advanced Laboratory Research in Biology, vol. III, pp. 195-199, 2012.

[83] K. Li, S. Liu, and X. Liu, "An overview of algae bioethanol production," International Journal of Energy Research, vol. 38, no. 8, pp. 965-977, 2014.

[84] I. Anastopoulos and G. Z. Kyzas, "Progress in batch biosorption of heavy metals onto algae," Journal of Molecular Liquids, vol. 209, pp. 77-86, 2015.

[85] A. Ahmad, S. M. Shah, M. F. Othman, and M. A. Abdullah, "Enhanced palm oil mill effluent treatment and biomethane production by co-digestion of oil palm empty fruit bunches with ", The Canadian Journal of Chemical Engineering, vol. 92, no. 9, pp. 1636-1642, 2014.

[86] J. Sheehan, T. Dunahay, J. Benemann, and P. Roessler, "Look back at the U.S. department of energy's aquatic species program: biodiesel from algae; close-out report," Tech. Rep. NREL/TP580-24190, 1998.

[87] Y. Li, M. Horsman, N. Wu, C. Lan, and N. Dubois-Calero, "Biofuels from Microalgae," Biotechnology Progress, vol. 24, pp. 815-820, 2008.

[88] D. Onyancha, W. Mavura, J. C. Ngila, P. Ongoma, and J. Chacha, "Studies of chromium removal from tannery wastewaters by algae biosorbents, Spirogyra condensata and Rhizoclonium hieroglyphicum," Journal of Hazardous Materials, vol. 158, no. 2-3, pp. 605-614, 2008.

[89] I. Moreno-garrido, J. Blasco, M. A. Gonzßlez-delvalle, and L. M. Lubißn, "Differences in copper accumulation by the marine microalga Nannochloropsis gaditana Lubißn," submitted to two different thermal treatments. Ecotoxicol Env Restor, vol. 1, pp. 4347, 1998.

[90] A. Sari and M. Tuzen, "Biosorption of $\mathrm{Pb}(\mathrm{II})$ and $\mathrm{Cd}(\mathrm{II})$ from aqueous solution using green alga (Ulva lactuca) biomass," Journal of Hazardous Materials, vol. 152, no. 1, pp. 302-308, 2008.

[91] Z. Chen, W. Ma, and M. Han, "Biosorption of nickel and copper onto treated alga (Undaria pinnatifida): Application of isotherm and kinetic models," Journal of Hazardous Materials, vol. 155, no. 1-2, pp. 327-333, 2008.

[92] S. Karthikeyan, R. Balasubramanian, and C. S. P. Iyer, "Evaluation of the marine algae Ulva fasciata and Sargassum sp. for the biosorption of $\mathrm{Cu}(\mathrm{II})$ from aqueous solutions," Bioresource Technology, vol. 98, no. 2, pp. 452-455, 2007.

[93] P. Kaewsarn, "Biosorption of copper(II) from aqueous solutions by pre-treated biomass of marine algae Padina sp." Chemosphere, vol. 47, no. 10, pp. 1081-1085, 2002.

[94] W. Mulbry, E. K. Westhead, C. Pizarro, and L. Sikora, "Recycling of manure nutrients: Use of algal biomass from dairy manure treatment as a slow release fertilizer," Bioresource Technology, vol. 96, no. 4, pp. 451-458, 2005.

[95] S. K. Mehta and J. P. Gaur, "Use of algae for removing heavy metal ions from wastewater: Progress and prospects," Critical Reviews in Biotechnology, vol. 25, no. 3, pp. 113-152, 2005. 
[96] J. He and J. P. Chen, "A comprehensive review on biosorption of heavy metals by algal biomass: materials, performances, chemistry, and modeling simulation tools," Bioresource Technology, vol. 160, pp. 67-78, 2014.

[97] A. Chan, H. Salsali, and E. McBean, "Heavy metal removal (copper and zinc) in secondary effluent from wastewater treatment plants by microalgae," ACS Sustainable Chemistry \& Engineering, vol. 2, no. 2, pp. 130-137, 2013.

[98] A. M. Abdel-Aty, N. S. Ammar, H. H. Abdel Ghafar, and R. K. Ali, "Biosorption of cadmium and lead from aqueous solution by fresh water alga Anabaena sphaerica biomass," Journal of Advanced Research, vol. 4, no. 4, pp. 367-374, 2013.

[99] D. Kaplan, "Absorption and Adsorption of Heavy Metals by Microalgae," in Handbook of Microalgal Culture: Applied Phycology and Biotechnology, A. Richmond and Hu. Q, Eds., pp. 602611, 2nd edition, 2013.

[100] T. Cai, S. Y. Park, and Y. Li, "Nutrient recovery from wastewater streams by microalgae: Status and prospects," Renewable \& Sustainable Energy Reviews, vol. 19, pp. 360-369, 2013.

[101] J. L. Wang and C. Chen, "Biosorbents for heavy metals removal and their future," Biotechnology Advances, vol. 27, no. 2, pp. 195226, 2009.

[102] G. Bayramoğlu, I. Tuzun, G. Celik, M. Yilmaz, and M. Y. Arica, "Biosorption of mercury(II), cadmium(II) and lead(II) ions from aqueous system by microalgae Chlamydomonas reinhardtii immobilized in alginate beads," International Journal of Mineral Processing, vol. 81, no. 1, pp. 35-43, 2006.

[103] W. Gekeler, E. Grill, E.-L. Winnacker, and M. H. Zenk, "Algae sequester heavy metals via synthesis of phytochelatin complexes," Archives of Microbiology, vol. 150, no. 2, pp. 197-202, 1988.

[104] X. Zeng, M. K. Danquah, R. Halim, S. Yang, X. D. Chen, and Y. $\mathrm{Lu}$, "Comparative physicochemical analysis of suspended and immobilized cultivation of Chlorella sp," Journal of Chemical Technology and Biotechnology, vol. 88, no. 2, pp. 247-254, 2013.

[105] X. Zeng, M. K. Danquah, R. Potumarthi, J. Cao, X. D. Chen, and $\mathrm{Y}$. Lu, "Characterization of sodium cellulose sulphate/polydimethyl-diallyl-ammonium chloride biological capsules for immobilized cultivation of microalgae," Journal of Chemical Technology and Biotechnology, vol. 88, no. 4, pp. 599-605, 2013.

[106] N. Mallick and L. C. Rai, "Removal of inorganic ions from wastewaters by immobilized microalgae," World Journal of Microbiology \& Biotechnology, vol. 10, no. 4, pp. 439-443, 1994.

[107] E. Eroglu, V. Agarwal, M. Bradshaw, X. Chen, S. M. Smith, and C. L. Raston, "Nitrate removal from liquid effluents using microalgae immobilized on chitosan nanofiber mats," Green Chemistry, vol. 14, no. 10, pp. 2682-2685, 2012.

[108] G. Bayramoğlu and M. Y. Arıca, "Construction a hybrid biosorbent using Scenedesmus quadricauda and Ca-alginate for biosorption of $\mathrm{Cu}(\mathrm{II}), \mathrm{Zn}(\mathrm{II})$ and $\mathrm{Ni}(\mathrm{II})$ : Kinetics and equilibrium studies," Bioresource Technology, vol. 100, no. 1, pp. 186-193, 2009.

[109] A. Nakajima, T. Horikoshi, and T. Sakaguchi, "Recovery of uranium by immobilized microorganisms," European Journal of Applied Microbiology and Biotechnology, vol. 16, no. 2-3, pp. 8891, 1982.

[110] D. W. Darnall, B. Greene, M. T. Henzl et al., "Selective recovery of gold and other metal ions from an algal biomass," Environmental Science \& Technology, vol. 20, no. 2, pp. 206-208, 1986.

[111] N. Akhtar, J. Iqbal, and M. Iqbal, "Removal and recovery of nickel(II) from aqueous solution by loofa sponge-immobilized biomass of Chlorella sorokiniana: characterization studies," Journal of Hazardous Materials, vol. 108, no. 1-2, pp. 85-94, 2004.

[112] G. Mujtaba, M. Rizwan, and K. Lee, "Removal of nutrients and COD from wastewater using symbiotic co-culture of bacterium Pseudomonas putida and immobilized microalga Chlorella vulgaris," Journal of Industrial and Engineering Chemistry, vol. 49, pp. 145-151, 2017.

[113] E. Safonova, K. V. Kvitko, M. I. Iankevitch, L. F. Surgko, I. A. Afti, and W. Reisser, "Biotreatment of industrial wastewater by selected algal-bacterial consortia," Engineering in Life Sciences, vol. 4, no. 4, pp. 347-353, 2004.

[114] A. Wilke, R. Buchholz, and G. Bunke, "Selective biosorption of heavy metals by algae," Journal of Petroleum and Environmental Biotechnology, vol. 2, pp. 47-56, 2006.

[115] I. Moreno-Garrido, O. Campana, L. M. Lubián, and J. Blasco, "Calcium alginate immobilized marine microalgae: Experiments on growth and short-term heavy metal accumulation," Marine Pollution Bulletin, vol. 51, no. 8-12, pp. 823-829, 2005.

[116] N. Akhtar, A. Saeed, and M. Iqbal, "Chlorella sorokiniana immobilized on the biomatrix of vegetable sponge of Luffa cylindrica: A new system to remove cadmium from contaminated aqueous medium," Bioresource Technology, vol. 88, no. 2, pp. 163-165, 2003.

[117] N. Akhtar, J. Iqbal, and M. Iqbal, "Microalgal-luffa sponge immobilized disc: A new efficient biosorbent for the removal of $\mathrm{Ni}(\mathrm{II})$ from aqueous solution," Letters in Applied Microbiology, vol. 37, no. 2, pp. 149-153, 2003.

[118] L. Travieso, R. O. Cañizares, R. Borja et al., "Heavy metal removal by microalgae," Bulletin of Environmental Contamination and Toxicology, vol. 62, no. 2, pp. 144-151, 1999.

[119] N. Mallick and L. C. Rai, "Influence of culture density, pH, organic acids and divalent cations on the removal of nutrients and metals by immobilized Anabaena doliolum and Chlorella vulgaris," World Journal of Microbiology and Biotechnology, vol. 9, no. 2, pp. 196-201, 1993.

[120] L. C. Rai and N. Mallick, "Removal and assessment of toxicity of $\mathrm{Cu}$ and $\mathrm{Fe}$ to Anabaena doliolum and Chlorella vulgaris using free and immobilized cells," World Journal of Microbiology \& Biotechnology, vol. 8, no. 2, pp. 110-114, 1992.

[121] A. C. A. da Costa and S. G. F. Leite, "Metals biosorption by sodium alginate immobilized Chlorella homosphaera cells," Biotechnology Letters, vol. 13, no. 8, pp. 559-562, 1991.

[122] S. C. Wilkinson, K. H. Goulding, and P. K. Robinson, "Mercury removal by immobilized algae in batch culture systems," Journal of Applied Phycology, vol. 2, no. 3, pp. 223-230, 1990.

[123] W. O. Wan Maznah, A. T. Al-Fawwaz, and M. Surif, "Biosorption of copper and zinc by immobilised and free algal biomass, and the effects of metal biosorption on the growth and cellular structure of Chlorella sp. and Chlamydomonas sp. isolated from rivers in Penang, Malaysia," Journal of Environmental Sciences, vol. 24, no. 8, pp. 1386-1393, 2012.

[124] N. Akhtar, M. Iqbal, S. I. Zafar, and J. Iqbal, "Biosorption characteristics of unicellular green alga Chlorella sorokiniana immobilized in loofa sponge for removal of Cr(III)," Journal of Environmental Sciences, vol. 20, no. 2, pp. 231-239, 2008.

[125] J. Shi, B. Podola, and M. Melkonian, "Removal of nitrogen and phosphorus from wastewater using microalgae immobilized on twin layers: An experimental study," Journal of Applied Phycology, vol. 19, no. 5, pp. 417-423, 2007.

[126] J.-P. Hernandez, L. E. De-Bashan, and Y. Bashan, "Starvation enhances phosphorus removal from wastewater by the 
microalga Chlorella spp. co-immobilized with Azospirillum brasilense," Enzyme and Microbial Technology, vol. 38, no. 1-2, pp. 190-198, 2006.

[127] M. V. Jimenez-Perez, P. Sánchez-Castillo, O. Romera, D. Fernández-Moreno, and C. Pérez-Martínez, "Growth and nutrient removal in free and immobilized planktonic green algae isolated from pig manure," Enzyme and Microbial Technology, vol. 34, no. 5, pp. 392-398, 2004.

[128] K. Abe, I. Matsumura, A. Imamaki, and M. Hirano, "Removal of inorganic nitrogen sources from water by the algal biofilm of the aerial microalga Trentepohlia aurea," World Journal of Microbiology and Biotechnology, vol. 19, pp. 325-328, 2003.

[129] N. F. Y. Tam and Y. S. Wong, "Effect of immobilized microalgal bead concentrations on wastewater nutrient removal," Environmental Pollution, vol. 107, no. 1, pp. 145-151, 2000.

[130] A. Ruiz-Marin, L. G. Mendoza-Espinosa, and T. Stephenson, "Growth and nutrient removal in free and immobilized green algae in batch and semi-continuous cultures treating real wastewater," Bioresource Technology, vol. 101, no. 1, pp. 58-64, 2010.

[131] S. Fierro, M. del Pilar Sánchez-Saavedra, and C. Copalcúa, "Nitrate and phosphate removal by chitosan immobilized Scenedesmus," Bioresource Technology, vol. 99, no. 5, pp. 12741279, 2008.

[132] J. Desmet, C. Meunier, E. Danloy et al., "Highly efficient, long life, reusable and robust photosynthetic hybrid core-shell beads for the sustainable production of high value compounds," Journal of Colloid and Interface Science, vol. 448, pp. 79-87, 2015. 


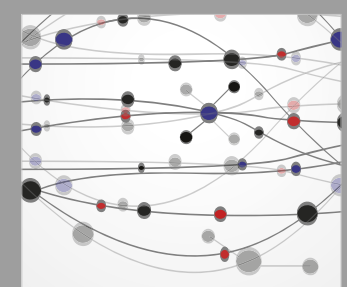

The Scientific World Journal
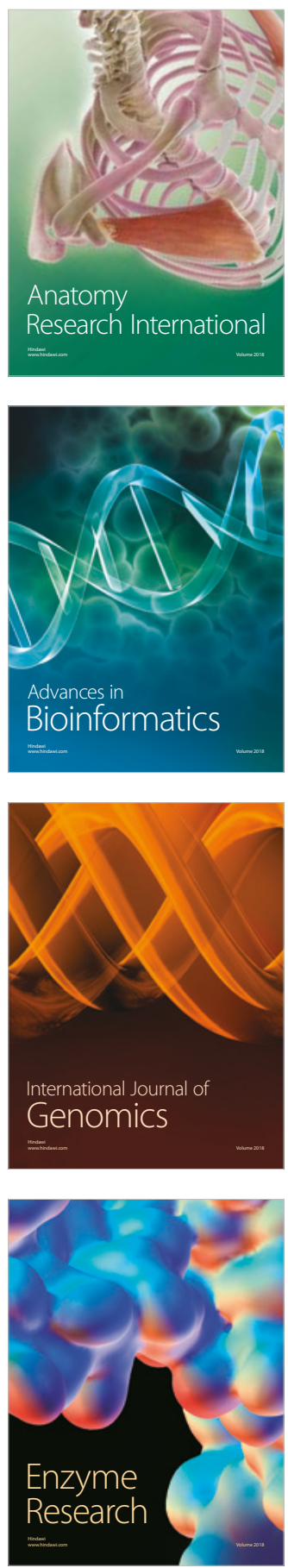
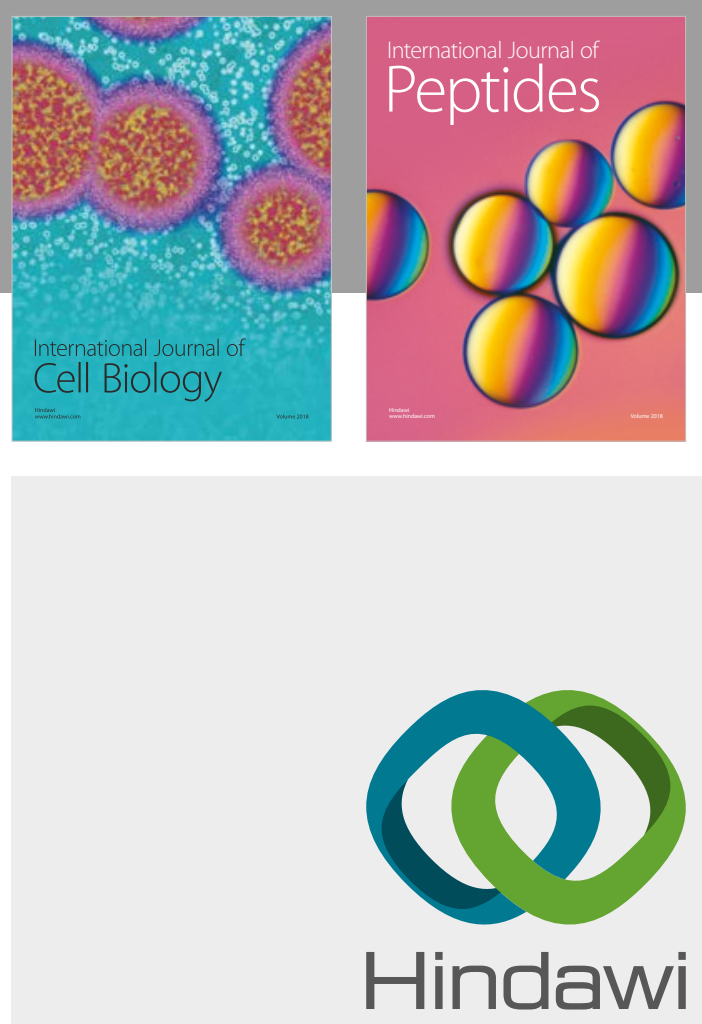

Submit your manuscripts at

www.hindawi.com
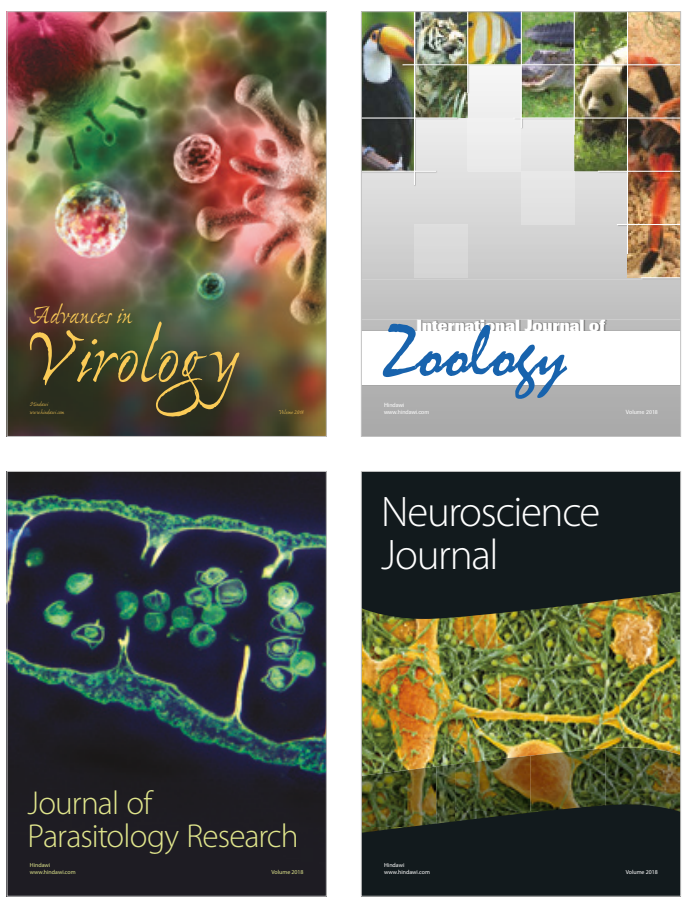
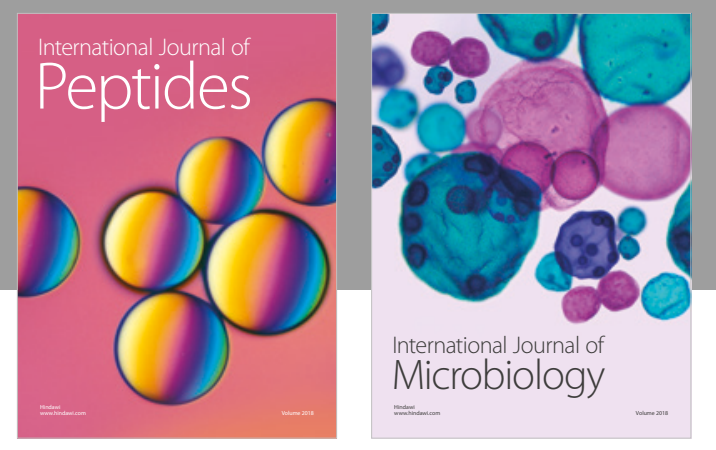

nternational Journal of Microbiology
Journal of
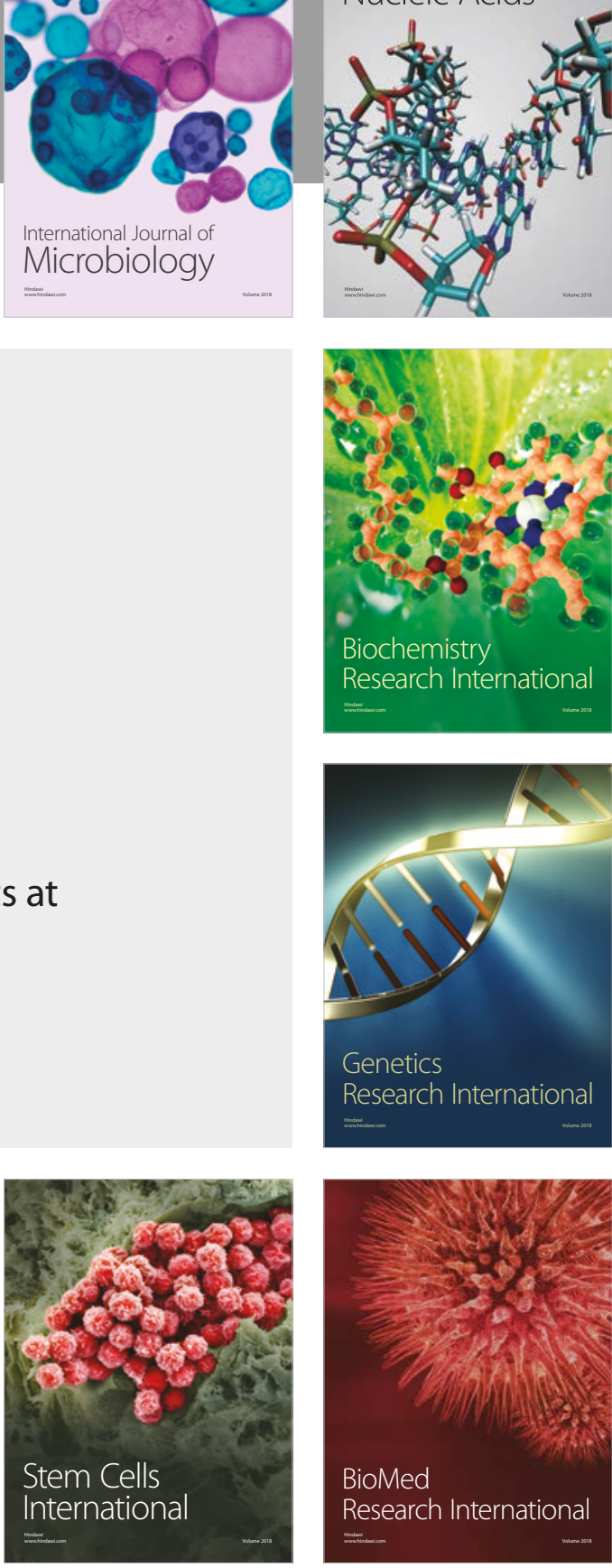
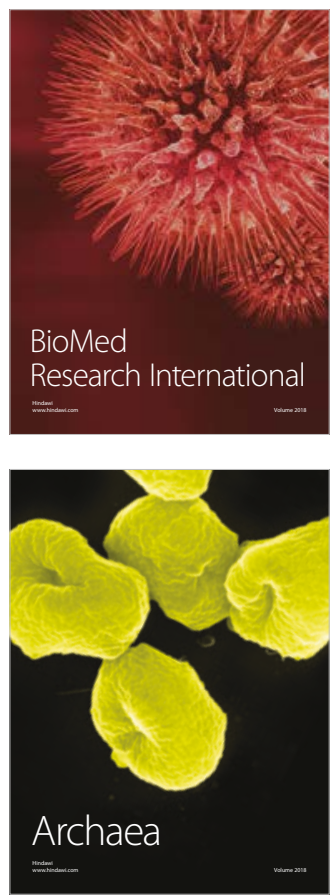